\title{
Employment status of workers with a diagnosed occupational disease in Croatia: a 10-year trend (2005-2014)
}

\author{
Renata Ecimović Nemarnik ${ }^{1}$ and Jelena Macan ${ }^{2}$ \\ Health Centre Zagreb-West ${ }^{1}$, Institute for Medical Research and Occupational Health ${ }^{2}$,Zagreb, Croatia
}

[Received in April 2018; Similarity Check in April 2018; Accepted in September 2018]

\begin{abstract}
Occupational diseases (ODs) often have a chronic, progressive course, resulting in reduced work capacity and quality of life, prolonged sick leaves, unemployment, early retirements, and disability claims. The aim of this retrospective study was to see how diagnosed ODs affected the employment of 95 Croatian workers between 2005 and 2014. To do that, we reviewed archived data and made a telephone survey. The lowest age at which an OD was diagnosed was 20 years in women and 22 in men, while the shortest duration of work before OD diagnosis was one year for both genders. The most common ODs were overuse syndromes on the arms, carpal tunnel syndrome in particular, diagnosed mostly in textile and office workers. Of the 95 participants, 12 lost their jobs since the OD diagnosis, 46 retired, and 37 continued to work. Significantly more participants became unemployed after OD diagnosis in the period 2010-2014 than 2005-2009 (9 out of $43,21 \%$, vs. 3 out of $52,6 \%, P<0.05$ ). Only five participants were included in an occupational rehabilitation programme. Our findings warn against the deterioration in care for workers diagnosed with OD in Croatia.
\end{abstract}

KEY WORDS: occupational rehabilitation; overuse syndromes; prevention; retirement; unemployment; work ability

In the $17^{\text {th }}$ century, Bernardino Ramazzini described occupational diseases (ODs) as those caused by work and/ or conditions at work in his book De morbis artificum diatriba, which paved the way for occupational medicine (1). The first list of ODs was established in 1925 by the International Labour Organization (ILO) (2), which has since then been expanded to three main chapters: 1) ODs caused by exposure to agents arising from work activities, including diseases caused by chemical, physical, and biological agents; 2) ODs by target organ systems, including respiratory, skin, musculoskeletal, and mental disorders; and 3) occupational cancers (3). In Croatia, ODs are covered by the List of Occupational Diseases Act and its amendment $(4,5)$. The Act defines an OD as a proven consequence of exposure to occupational hazards and is in line with the $\mathrm{OD}$ list established by ILO in 2010.

ODs often have a chronic, progressive course, resulting in reduced work capacity and quality of life of a patient, prolonged sick leaves, unemployment, early retirements, and disability claims. They can have a substantial negative social and financial effect on the individual and national levels (6). ODs regularly cause some kind of permanent work disability in a patient, but this disability is usually limited to a specific workplace or profession. Patients with ODs in most cases cannot continue to work on the same job or even in their profession. Their work capacity can be preserved by occupational rehabilitation, retraining for a

Correspondence to: Jelena Macan, Institute for Medical Research and Occupational Health, Zagreb, Croatia, E-mail:jmacan@imi.hr different profession, or additional training within the same profession. In Croatia, occupational rehabilitation for the workforce (employed and unemployed) whose work capacity has been significantly reduced is provided by local centres for occupational rehabilitation (7).

As data in this field are scarce for Croatian workers, the aim of this study was to evaluate the employment status of workers with diagnosed OD and the efficiency of measures taken to preserve their work capacity. We wanted to establish which ODs were diagnosed, which workplaces/ professions caused them, how many patients received occupational rehabilitation services, and what the unemployment and retirement rates were in workers with a diagnosed OD.

\section{PARTICIPANTS AND METHODS}

The invited participants were patients with ODs $(\mathrm{N}=147)$ diagnosed by the occupational and sports medicine outpatient clinic at the Institute for Medical Research and Occupational Health (IMROH), Zagreb, Croatia, between 2005 and 2014. Among them, three declined to participate, four died, and four could not be reached. Of the remaining 136 patients, 95 who signed informed consent were included in the study. Those who were not included did not differ significantly from our study population in terms of age and gender distribution (data not shown). 
The study was approved by the ethics committees of IMROH and the Zagreb University School of Medicine and conducted in accordance with the Helsinki Declaration (8).

The study was split into two parts. First we reviewed participant records to verify their personal information (age, gender, profession, and length of service), OD diagnosis, and the characteristics of work that caused the OD. Then we conducted a telephone survey based on a questionnaire developed in Iceland for the assessment of work ability (9). We asked the participants if they were employed, unemployed, or retired. The employed participants were then asked if they worked for the same or different employer and if they had been offered occupational rehabilitation services after the OD had been diagnosed. The unemployed participants were asked the same question and what reason they were given for the termination of the employment contract. Questions about the length of service included total length of service and the length of service until OD diagnosis. We also asked all participants about their sources of income after the diagnosis.

Data were processed with descriptive statistics and further analysed with univariate statistics ( $\chi^{2}$ test, $t$-test) using STATA/SE 11.2 for Windows (StataCorp LP, College Station, TX, USA). $\mathrm{P}<0.05$ was considered statistically significant.

\section{RESULTS AND DISCUSSION}

Table 1 shows the participants' age and length of service. The lowest age at OD diagnosis was 20 years in women and 22 in men, while the shortest service before OD diagnosis was one year for both genders. The participant with the shortest length of service before OD diagnosis (one year) repaired car batteries, and his occupational exposure resulted in lead poisoning. The shortest length of service before OD diagnosis among women was 1.5 years in a hairdresser who developed allergic contact dermatitis caused by sensitisation to hairdressing chemicals (para-

Table 1 Age and length of service among the study participants with diagnosed occupational disease $(N=95)$

\begin{tabular}{|c|c|c|c|}
\hline & Women & Men & \multirow{2}{*}{$\mathbf{P}$} \\
\hline & $\mathrm{N}=52$ & $\mathrm{~N}=43$ & \\
\hline \multirow{2}{*}{$\begin{array}{l}\text { Age, } \mathrm{X} \pm \mathrm{SD} \text { (range), } \\
\text { years }\end{array}$} & $53 \pm 8.4$ & $57 \pm 8.9$ & \multirow{2}{*}{$0.034 *$} \\
\hline & $(22-73)$ & $(29-74)$ & \\
\hline \multirow{2}{*}{$\begin{array}{l}\text { Age OD, } \mathrm{X} \pm \mathrm{SD} \\
\text { (range), years }\end{array}$} & $47 \pm 7.6$ & $50 \pm 8.9$ & \multirow{2}{*}{ n.s. } \\
\hline & $(20-67)$ & $(22-67)$ & \\
\hline \multirow{2}{*}{$\begin{array}{l}\text { Length of service, } \\
\mathrm{X} \pm \mathrm{SD} \text { (range), years }\end{array}$} & $26 \pm 7.5$ & $27 \pm 8.9$ & \multirow{2}{*}{ n.s. } \\
\hline & $(1-37)$ & $(3-41)$ & \\
\hline \multirow{2}{*}{$\begin{array}{l}\text { Length of service OD, } \\
\mathrm{X} \pm \mathrm{SD} \text { (range), years }\end{array}$} & $22 \pm 8.7$ & $22 \pm 9.7$ & \multirow{2}{*}{ n.s. } \\
\hline & $(1-35)$ & $(1-40)$ & \\
\hline
\end{tabular}

Age OD - age at which an OD was diagnosed; Length of service $O D$ - years of service at the workplace that caused the OD; n.s. - not significant $(P>0.05) ; * t$-test phenylenediamine, ammonium persulfate, and colophonium). The longest service before OD diagnosis (35-40 years) was reported by the participants occupationally exposed to asbestos.

Depending on the pathophysiology and individual risk factors, ODs can occur shortly after a person starts to work. Such ODs call for particular care, as they may result in permanent disability, preventing young people to continue working in the profession for which they have been trained. Judging by earlier reports (10), the hairdresser in our study had already experienced exposure to occupational allergens and the first symptoms of her OD during apprenticeship. These issues seem to reflect poor vocational guidance and medical surveillance of apprentices training for hazardous occupations. Another reason for early OD is poor safety at work, as illustrated by the young man who had lead poisoning from car batteries early in his career.

Figure 1 show the top eight professions with diagnosed ODs by gender. If both genders are combined, OD was most often diagnosed in unskilled workers employed in various trades, followed by textile workers, hairdressers, loggers, and car repair workers.

Table 2 shows the distribution of ODs by gender (11). In women, the most common were the carpal tunnel and other overuse syndromes on the arm, as well as allergic and irritant contact dermatitis. In men, the most common OD was vibration hand/arm syndrome. Asthma was equally present in both genders. The carpal tunnel syndrome was most common among textile workers $(\mathrm{N}=12)$ and administrative workers $(\mathrm{N}=5)$, allergic contact dermatitis among hairdressers $(\mathrm{N}=7)$, irritant contact dermatitis among unskilled workers of various trades $(\mathrm{N}=8)$, vibration hand and arm syndrome in loggers $(\mathrm{N}=7)$, and asthma in healthcare workers $(\mathrm{N}=4)$.

The Croatian register of occupational diseases (12) lists among the most frequent ODs in 2010-2014 skin and respiratory diseases and overuse syndromes caused by cumulative trauma or vibration, which is in accordance with our findings. According to Eurostat (13), the most common work-related disorders in the EU are musculoskeletal disorders and hand overuse syndromes in particular, which also confirms our findings, singling out the carpal tunnel syndrome as the most common OD in textile and office workers. All these overuse disorders have been well described in literature (e.g. 14, 15), but it is important to highlight the occupational upper body overuse syndromes associated with computer-related activities mostly carried out by office workers - jobs that also include daily hand and arm strains. The observed gender differences in specific ODs seem to reflect the traditional, gender-based division of labour. Women seem to dominate at jobs associated with significant risks of occupational hand overuse syndromes and skin diseases. Beside the carpal tunnel syndrome mentioned above - associated with textile and office workers - skin diseases, contact allergic and irritant dermatitis, are quite common in traditionally "female" 


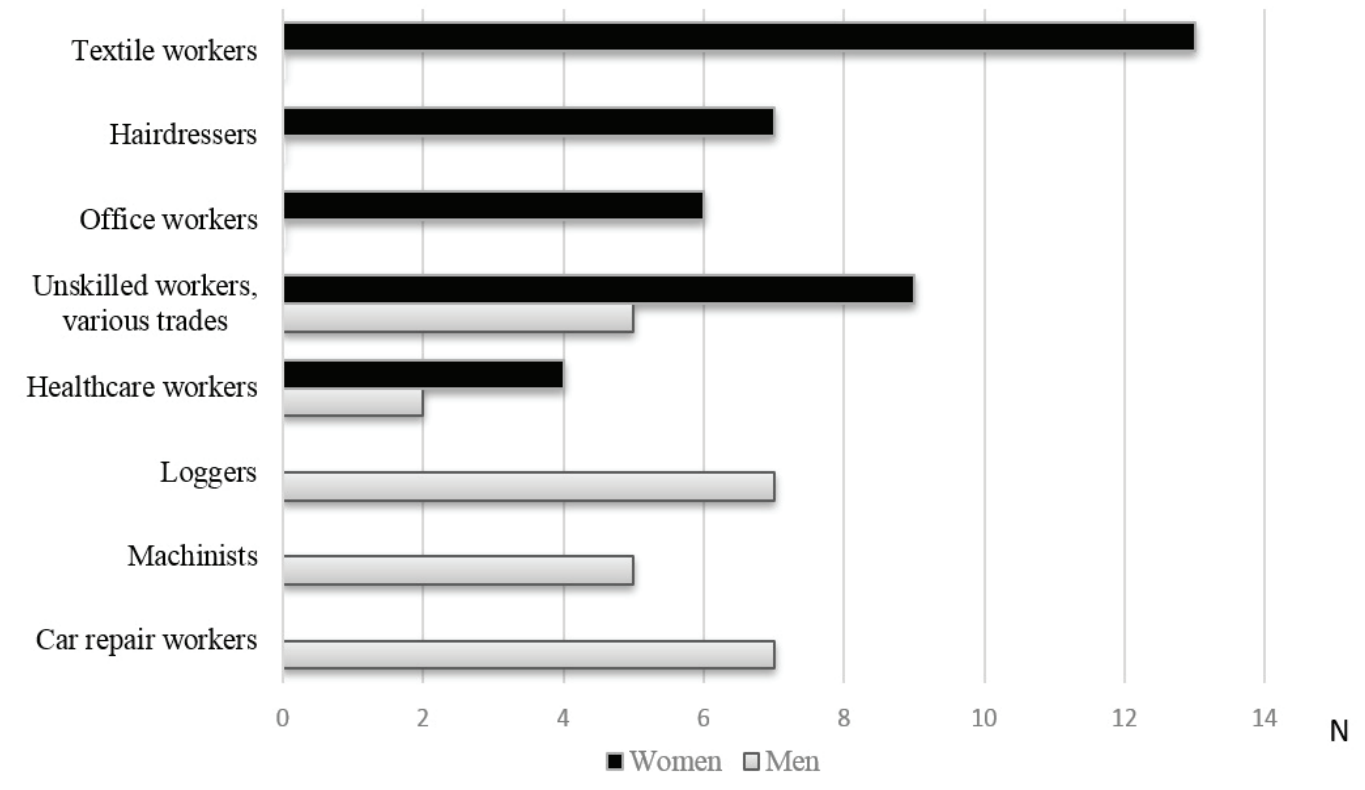

Figure 1 Workplaces where the majority of ODs were diagnosed by gender. N=number of participants with diagnosed OD

professions such as hairdressers and cleaners, whose skin is in contact with harmful chemicals (16). As for men, the most common ODs were vibration and overuse hand/arm syndromes associated with vehicle maintenance (mechanics) and tool handling (loggers).

Figure 2 shows that 59 participants were let go and remained unemployed after OD diagnosis, but no differences between the genders were observed (data not shown). In fact, the unemployment figures significantly increased in the second half of the study period (2010-2014,
Figure 2b) compared to the first half (2005-2009, Figure 2c) $(\mathrm{P}=0.033$; Fisher exact test $)$.

Five of the 12 unemployed participants over the entire study period (2005-2014) (41.66\%) applied for benefits and sought employment at the Croatian Employment Service and only one participant $(8.33 \%)$ received occupational rehabilitation - the 22-year-old hairdresser with 1.5 years of service.

Unemployed participants lost their jobs either because they were dismissed (10 participants or $83 \%$ ) or the company was liquidated ( 2 participants or $17 \%$ ). Of the 36

Table 2 Occupational diseases diagnosed at the Institute for Medical Research and Occupational Health (Zagreb, Croatia) and considered within this study

\begin{tabular}{lccc}
\hline Occupational disease (ICD-10 code) (11) & Women & Men & Total \\
\hline Carpal tunnel syndrome (G56) & 17 & 4 & 21 \\
\hline Allergic contact dermatitis (L23) & 10 & 3 & 13 \\
\hline Irritant contact dermatitis (L24) & 8 & 3 & 11 \\
\hline Vibration hand/arm syndrome (W43) & 0 & 10 & 10 \\
\hline Asthma (J45) & 6 & 4 & 10 \\
\hline Overuse syndromes on the arms (M56, M65.4, M70, M75, M77) & 4 & 3 & 7 \\
\hline Viral hepatitis C (B18.2) & 2 & 3 & 5 \\
\hline Hearing loss (H90.3) & 1 & 4 & 5 \\
\hline Pleural plaque with or without asbestosis (J92) & 1 & 2 & 3 \\
\hline Lead poisoning (T56) & 0 & 2 & 2 \\
\hline Toxic encephalopathy (G92, F02) & 0 & 2 & 2 \\
\hline Lung tuberculosis (A15) & 1 & 0 & 1 \\
\hline Legionnaires' disease (A48.1) & 0 & 1 & 1 \\
\hline Risarthrosis (M18) & 1 & 0 & 1 \\
\hline Knee meniscus damage (M23.3) & 0 & 1 & 1 \\
\hline Allergic rhinitis (J30) & 1 & 0 & 1 \\
\hline Vocal cord nodules (J38.2) & 0 & 1 & 1 \\
\hline
\end{tabular}



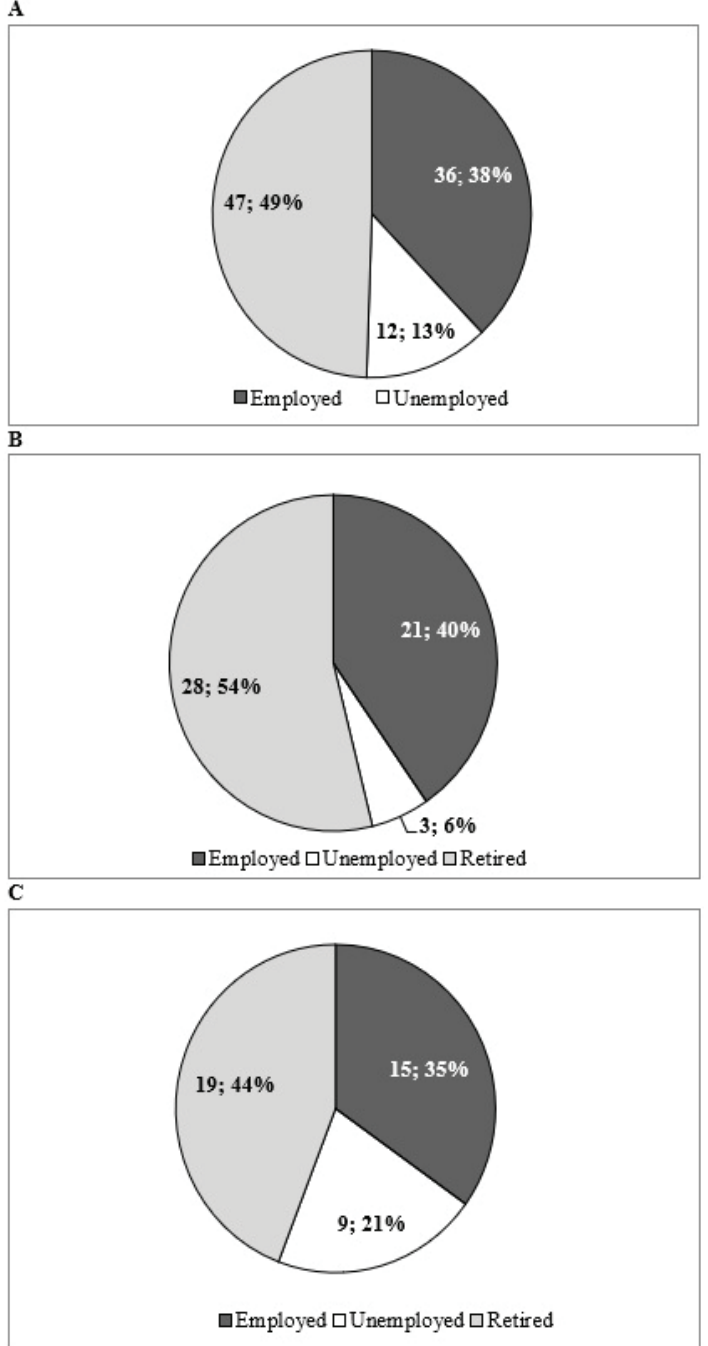

Figure 2 Employment status of the participants after $O D$ diagnosis. A: 2005-2014 (N=95); B: 2005-2009 (N=52); C: 2010 $2014(N=43)$

participants who were employed, 28 (77.8\%) remained with the same employer after OD diagnosis, 21 of whom at the same workplace and seven on another position. Of the eight participants who changed employer after OD diagnosis, four received occupational rehabilitation.

As many as 35 out of the 47 retired subjects $(74.5 \%)$ opted for disability pension, while the rest took regular or early retirement pensions.

Eighty-three of the 95 participants $(87.4 \%)$ had permanent sources of income after OD diagnosis, most of them disability pensions, and $12(12.6 \%)$ had no source of income.

However limited in sample, our study clearly shows that people with OD receive inadequate care in Croatia, which is getting even worse. Our findings are consistent with similar earlier surveys conducted in Croatia $(17,18)$, which point to the increasing trend among employers of firing workers with a diagnosed OD instead of retraining them or adapting the workplace. Social institutions do even worse, as they fail to do their job: rehabilitate the workers and provide training in other professions. The success of occupational rehabilitation (vocational interventions or re-employment programmes) has already been demonstrated $(19,20)$, but there is still a lot of room left for improvement.

The situation is not good even with the participants who have remained employed ( 36 or $38 \%$ ), as 21 of them remained with the same employer and at the same workplace which caused the OD. It is only a question of time when their work capacity will be permanently lost. Workers such as these remain at their jobs because unemployment in Croatia is high and finding a more appropriate job is difficult. Rare are the cases where employers improve or introduce new safety measures at work to minimise the occupational risk, so that remaining at the same workplace can be justified. This survey, however, did not address these issues.

The largest group of the participants in this survey were the retired ones (49\%), three quarters of whom were on disability pension, which also makes the main income source for the majority of our participants. Again, these figures reflect the poor functioning of occupational rehabilitation in Croatia. Generally in Croatia, sick leaves due to occupational injuries or ODs last longer than sick leaves due to other diseases (21). Eventually, instead of receiving occupational rehabilitation, such patients receive disability pensions or become unemployed. Between 2005 and 2010, the number of disability pension beneficiaries in Croatia increased $8 \%$. In 2005, the share of disability pensions in total pension cost was $26.2 \%$, while in the EU countries it was $15.9 \%$ (6). However, disability pensions are often insufficient to cover the basic needs.

Our findings also reflect the attempts made since 2010 to reduce the number of early retirements at the national level in Croatia. However, these were not followed by improvements in the occupational rehabilitation system. Instead of re-employment, unemployment soared (Figure 2c).

Early diagnosis of ODs, termination of work which caused the OD, and referral to occupational rehabilitation is paramount to resolving these issues and maintaining the work capacity of the affected workers. If the disease has advanced, however, it is the job of occupational experts working with authorities to prevent complications, reduce disability, and rehabilitate an individual to the extent possible (22).

Our study clearly indicates that this system does not work in Croatia. It should start with strengthening OD prevention to maintain worker health for as long as possible, and improving occupational rehabilitation to keep workers employed. This issue should be addressed not only by workers, employers, and doctors, but by the whole community. 


\section{Acknowledgements}

This work was funded by the Institute for Medical Research and Occupational Health, Zagreb, Croatia. We would like to thank Mrs Marija Lieberth for a great help in recruiting the participants and Mrs Franka Šakić for data analysis.

\section{REFERENCES}

1. Franco G, Franco F. Bernardino Ramazzini: The father of occupational medicine. Am J Public Health 2001;91:1382. doi: 10.2105/AJPH.91.9.1382

2. Kim EA, Kang SK. Historical review of the List of Occupational Diseases recommended by the International Labour Organization (ILO). Ann Occup Environ Med 2013;25:14. doi: 10.1186/2052-4374-25-14

3. International Labour Organization (ILO). List of Occupational Diseases (revised 2010). [displayed 2 August 2018] Available at http://www.ilo.org/safework/info/publications/ WCMS 125137/lang--en/index.htm

4. Zakon o listi profesionalnih bolesti [List of occupational diseases act, in Croatian). Narodne novine 162/1998.

5. Zakon o izmjenama i dopunama Zakona o listi profesionalnih bolesti [Amendment on the List of occupational diseases act, in Croatian]. Narodne novine 107/2007.

6. International Labour Organization (ILO). The Prevention of Occupational Diseases. World Day for Safety and Health at Work, 28 April 2013 [displayed 2 August 2018]. Available at http://www.ilo.org/safework/info/publications/ WCMS_208226/lang--en/index.htm

7. Zakon o profesionalnoj rehabilitaciji i zapošljavanju osoba $\mathrm{s}$ invaliditetom [Vocational rehabilitation and employment of people with disability act, in Croatian]. Narodne novine 157/2013.

8. World Health Organisation. World Medical Association Declaration of Helsinki. Ethical principles for medical research involving human subjects. Bull WHO 2001;79:3734.

9. Konráðsdóttir ÁD. Work ability assessment - description and evaluation of a new tool in vocational rehabilitation and in disability claims [MSc thesis]. Bifröst: University of Bifröst; 2011.

10. Samardžić T, Varnai VM, Bakotić M, Babić Ž, Brans R, Cvijetić Avdagić S, Štampar Šmaguc D, Kovačević I, Macan J. Skin health and safety at work in Croatian hairdressing apprentices. Contact Dermatitis 2016;75:25-31. doi: 10.1111/ cod. 12603

11. ICD-10: International statistical classification of diseases and related health problems: tenth revision. $2^{\text {nd }}$ ed. Geneva: WHO, 2009.

12. Croatian Institute for Health Protection and Safety at Work. Profesionalne bolesti u Republici Hrvatskoj (2006-2017)
[Register of occupational diseases (2006-2017), in Croatian] [displayed 2 August 2018]. Available at http://hzzzsr.hr/index. $\mathrm{php} /$ porefesionalne-bolesti-i-ozljede-na-radu/profesionalnebolesti/profesionalne-bolesti-u-republici-hrvatskoj/

13. Eurostat. Health and safety at work in Europe (1999-2007) - a statistical portrait, 2010 [displayed 2 August 2018]. Available at http://ec.europa.eu/eurostat/ documents/3217494/5718905/KS-31-09-290-EN. PDF/88eef9f7-c229-40de-b1cd-43126bc4a946

14. European Agency for Safety and Health at Work. Workrelated neck and upper limb musculoskeletal disorders: Summary of Agency report, 2000 [displayed 2 August 2018]. Available at https://osha.europa.eu/en/publications/ factsheets $/ 5$

15. Newington L, Harris EC, Walker-Bone K. Carpal tunnel syndrome and work. Best Pract Res Cl Rh 2015;29:440-53. doi: 10.1016/j.berh.2015.04.026

16. De Craecker W, Roskams N, De Beeck RO. European Risk Observatory Report. Occupational skin diseases and dermal exposure in the European Union (EU-25): policy and practice overview, 2008 [displayed 2 August 2018]. Available at https://osha.europa.eu/en/publications/reports/ TE7007049ENC_skin_diseases

17. Bubaš $M$, Milošević $\bar{M}$, Delić-Brkljačić D. Occupational diseases, working ability and employment status in the working population of Croatia. Coll Antropol 2008;32:67780. PMID: 18982736

18. Zahariev Vukšinić K. Profesionalna bolest kao osobni i gospodarski problem. [Occupational disease as an individual and economic problem, in Croatian] [MSc thesis]. Zagreb: Medicinski fakultet Sveučilišta u Zagrebu; 2014.

19. Audhoe SS, Hoving JL, Sluiter JK, Frings-Dresen MH. Vocational interventions for unemployed: effects on work participation and mental distress. A systematic review. J Occup Rehabil 2010;20:1-13. doi: 10.1007/s10926-0099223-y

20. van Rijn RM, Carlier BE, Schuring M, Burdorf A. Work as treatment? The effectiveness of re-employment programmes for unemployed persons with severe mental health problems on health and quality of life: a systematic review and metaanalysis. Occup Environ Med 2016;73:275-9. doi: 10.1136/ oemed-2015-103121

21. Bađun M. Doprinos za zaštitu zdravlja na radu [Contribution to the protection of health at work, in Croatian]. Newsletter 2016;106:1-13. doi: 10.3326/nlh.2016.106

22. Alfonso JH, Bauer A, Bensefa-Colas L, Boman A, Bubas M, Constandt L, Constandt L, Crepy MN, Goncalo M, Macan J, Mahler V, Mijakoski D, Ramada Rodilla JM, Rustemeyer T, Spring P, John SM, Uter W, Wilkinson M, Giménez-Arnau AM. Minimum standards on prevention, diagnosis and treatment of occupational and work-related skin diseases in Europe - position paper of the COST Action StanDerm (TD 1206). J Eur Acad Dermatol Venereol 2017;31(Suppl 4):3143. doi: $10.1111 / j d v .14319$ 


\section{Radni status radnika s dijagnosticiranom profesionalnom bolesti u Hrvatskoj od 2005. do 2014.}

Profesionalne bolesti često su kroničnog progresivnog tijeka te u pravilu značajno umanjuju radnu sposobnost i opću kvalitetu života oboljele osobe, produljuju razdoblje bolovanja, često dovode do gubitka posla ili ranog umirovljenja i predmetom su radničkih tužbi za naknadu štete. Cilj ovoga rada bio je istražiti učinke prijave profesionalne bolesti na radni status hrvatskih radnika u desetogodišnjem razdoblju. U istraživanje je bilo uključeno 95 bolesnika kod kojih je dijagnosticirana profesionalna bolest $u$ ambulanti medicine rada i sporta iz Zagreba u razdoblju 2005.-2014. Istraživanje je uključivalo pregled arhiviranih podataka u kartoteci ambulante i telefonsku anketu kojom su prikupljeni podatci o radnom statusu bolesnika nakon dijagnosticiranja profesionalne bolesti. Najniža dob u kojoj je profesionalna bolest dijagnosticirana u žena bila je 20 godina i 22 godine u muškaraca, a najkraći radni staž do utvrđivanja profesionalne bolesti iznosio je jednu godinu za oba spola. Najčešće dijagnosticirane profesionalne bolesti bile su sindromi prenaprezanja na rukama, naročito sindrom karpalnog tunela. Uz tekstilne radnike-šivače, ta je bolest najčešće utvrđena na radnim mjestima s uredskim poslovima koji uključuju rad na računalu. Kod 59 ispitanika (62 \%) došlo je do promjene radnog statusa nakon dijagnosticiranja profesionalne bolesti. Nakon priznavanja profesionalne bolesti 36 ispitanika (38 \%) ostalo je zaposleno, 12 (13\%) bilo je nezaposleno, a 47 (49\%) je umirovljeno. Postupcima profesionalne rehabilitacije bilo je obuhvaćeno 5 ispitanika (5\%). Udio nezaposlenih ispitanika nakon dijagnosticiranja profesionalne bolesti bio je značajno veći u razdoblju 2010.-2014. u odnosu na razdoblje 2005.-2009. [9 od 43 (21 \%) prema 3 od 52 (6\%), P<0,05]. Rezultati upućuju na neodgovarajuće zbrinjavanje radnika s profesionalnim bolestima u Hrvatskoj, s trendom sve češćeg otpuštanja radnika s dijagnosticiranom profesionalnom bolesti od 2000. godine do danas, uz nedostatnu provedbu postupaka profesionalne rehabilitacije.

KLJUČNE RIJEČI: nezaposlenost; prevencija; profesionalna rehabilitacija; radna sposobnost; sindromi prenaprezanja; umirovljenje 